\title{
The potential for intraspecific horizontal gene exchange by natural genetic transformation: sexual isolation among genomovars of Pseudomonas stutzeri
}

\author{
Michael G. Lorenz ${ }^{1}$ and Johannes Sikorski
}

\footnotetext{
1 Marine Mikrobiologie, Fachbereich

Biologie/Chemie, Zentrum für Umweltforschung und Umwelttechnologie, Universität Bremen, D-28359 Bremen, Germany

2 Genetik, Fachbereich Biologie, Universität Oldenburg, Postfach 2503, D-26111 Oldenburg, Germany
}

\author{
Author for correspondence: Michael G. Lorenz. Tel: +49 421218 7224. Fax: +49421 2187222. \\ e-mail:mglorenz@biotec.uni-bremen.de
}

\begin{abstract}
The potential for natural genetic transformation among the seven genomovars (gvs) of Pseudomonas stutzeri was investigated. Of the 12 strains originating from a variety of environments, six strains (50\%) from five gvs were competent for DNA uptake (Rif ${ }^{R}$ marker). The transformation frequencies varied over more than three orders of magnitude. With three highly transformable strains (ATCC 17587, ATCC 17641, JM300) from two gvs and all other strains as DNA donors, sexual isolation from other pseudomonad species (Pseudomonas alcaligenes, Pseudomonas mendocina) and also from other $P$. stutzeri gvs was observed (i.e. heterogamic transformation was reduced). For ATCC 17587 (gv 2) and ATCC 17641 (gv 8), heterogamic transformation was up to two and three orders of magnitude lower with other $P$. stutzeri gv and the other species employed, respectively, than in homogamic transformations. Interestingly, whereas with ATCC 17587 and ATCC 17641 heterogamic transformation with donors of the same gv was as high as homogamic transformation, JM300 (gv 8) was sexually isolated from its nearest relative (ATCC 17641). Also, sexual isolation of JM300 from other P. stutzeri gvs was most pronounced among the recipients tested, in some cases reaching the highest levels found with the other species as DNA donors (reduction of heterogamic transformation by $\mathbf{4 0 0 0}$-fold). Results obtained here from nucleotide sequence analysis of part (422 $\mathrm{nt}$ ) of the gene for the RNA polymerase $\beta$ subunit (rpoB) from various strains indicated that sexual isolation of ATCC 17641 increased with nucleotide sequence divergence. Implications of the observed great heterogeneity in transformability, competence levels and sexual isolation among strains are discussed with regard to the evolution of $P$. stutzeri.
\end{abstract}

Keywords: Pseudomonas stutzeri, genomovars, heterogamic transformation, sexual isolation, $r p o B$ phylogeny

\section{INTRODUCTION}

If recombination in the course of horizontal gene exchange occurs in the environment at rates that are high compared to mutation rates at gene loci, a mosaic structure of allele combinations will be favoured (Maynard Smith et al., 1991). Population structures indicating high recombination rates have been found

The EMBL accession numbers for the sequences reported in this paper are given in Methods. with pathogens like Helicobacter pylori, Neisseria gonorrhoeae, Neisseria meningitidis and Streptococcus pneumoniae, and saprophytic bacteria including Bacillus subtilis and Burkholderia cepacia on the grounds of multilocus enzyme electrophoresis or multilocus restriction typing analyses (Duncan et al., 1994; Go et al., 1996; Haubold et al., 1998; Istock et al., 1992; Maynard Smith et al., 1993; Müller-Graf et al., 1999; Roberts \& Cohan, 1995; Wise et al., 1995). Genetic diversity created by recombination may help adapt these organisms to adverse environmental conditions or help them overcome a host's defence mechanisms (Robertson 
\& Meyer, 1992). Despite high recombination rates in some species like B. subtilis (Istock et al., 1992), distinct groups within populations are found which may have developed because of adaptive divergence with the result of reduced recombination rates, i.e. sexual isolation (Cohan et al., 1991).

An increasing body of evidence points at natural genetic transformation as an important mechanism of the horizontal exchange of genes (Dubnau, 1999; Lorenz \& Wackernagel, 1994; Paget \& Simonet, 1994). Natural genetic transformation (termed transformation in the following) is a gene-transfer process which involves the binding of exogenous DNA to specific cell surface receptors, DNA processing (including degradation of one strand) and the subsequent active transport of single-stranded DNA into the cytoplasm where it is recombined with the recipient chromosome (for reviews see Dubnau, 1999; Grossman, 1995; Lorenz \& Wackernagel, 1994). Transformation is unique to the domains Bacteria and Archaea (Lorenz, 1998). More than 40 species have been described as being transformable so far belonging to phylogenetic branches such as the Proteobacteria, Green Sulphur Bacteria, Cyanobacteria, low and high $\mathrm{G}+\mathrm{C}$ bacteria (Firmicutes), the Deinococcus-Thermus group and the Euryarchaeota. This, together with the homology of competence genes among Gram-negative and Gram-positive bacteria (Dubnau, 1999), suggests that transformation is a phylogenetically old property. Transformation appears to take place at all environmental sites where bacteria live, among them the marine, freshwater, soil and plant environments (Bertolla et al., 1999; Lorenz \& Wackernagel, 1994; Paget \& Simonet, 1994). Studies performed so far with respect to sexual isolation in naturally transformable species and the mechanisms behind it have included mainly B. subtilis and Haemophilus influenzae (Albritton et al., 1984; Roberts \& Cohan, 1993; for a review see Lorenz \& Wackernagel, 1994). The most intensive study performed so far included a desert soil population of $B$. subtilis where sexual isolation among subpopulations and between $B$. subtilis and other named Bacillus species was shown to rely on DNA restriction (albeit only marginally) and nucleotide sequence divergence of the donor DNA from the recipient chromosome (Majewski \& Cohan, 1999; Roberts \& Cohan, 1993; Zawadzki et al., 1995).

The naturally transformable ubiquitous saprophyte, Pseudomonas stutzeri, is a promising organism to investigate gene transfer and sexual isolation mechanisms because the species has a well defined taxonomic substructure. DNA-DNA hybridizations have shown the existence of seven genomovars (Rosselló et al., 1991; Rosselló-Mora et al., 1996). The genomovar structure of $P$. stutzeri is consistent with the finding of seven genotypic groups in a genomic fingerprint analysis (Sikorski et al., 1999). Variable grouping of various strains in cluster analyses of genomic fingerprints and macrorestriction patterns indicated that chromosomal rearrangements, presumably also a result of horizontal gene transfer, have occurred and contributed to the extremely high genotypic diversity within this species (Bennasar et al., 1998; Ginard et al., 1997; Rainey et al., 1994; Sikorski et al., 1999).

Here quantitative data are presented on the transformability and heterogamic transformation of $P$. stutzeri strains affiliated to the seven genotypic groups. Possible mechanisms and evolutionary implications of the observed sexual isolation among and within groups are discussed.

\section{METHODS}

Strains, media and DNA preparation. The strains used in this study and their affiliation to genotypic groups as defined by Sikorski et al. (1999) are listed in Table 1. The collection comprised most of the strains that have been characterized before with respect to their clustering on the grounds of the $16 \mathrm{~S}$ rRNA gene, DNA hybridization and genomic fingerprinting analyses (Sikorski et al., 1999; see Table 1). For DNA competition experiments (see Fig. 2), JM306 (leu), a derivative of JM300 (Carlson et al., 1983), was used as a source of homogamic non-transforming DNA. Strains were grown in LB medium (Davis et al., 1980). Determination of viable counts and rifampicin-resistant $\left(\mathrm{Rif}^{\mathrm{R}}\right)$ counts was done by plating cells on LB agar and LB agar containing $100 \mu \mathrm{g}$ rifampicin $\mathrm{ml}^{-1}$, respectively. Chromosomal DNA was extracted from cells and purified following the procedure of Marmur (1961). The DNA was dissolved in $10 \mathrm{mM}$ Tris/ $\mathrm{HCl}$, pH 8.0, 1 mM EDTA. Phage P22 DNA was purified following the procedure of Hermanns \& Wackernagel (1977).

Plate transformation assay. One millilitre of overnight grown stationary cultures $(5 \mathrm{ml})$ of the strains was centrifuged (13000 r.p.m., Eppendorf centrifuge) for $3 \mathrm{~min}$. The pellet was resuspended in a $0.9 \% \mathrm{NaCl}$ solution, centrifuged again and finally resuspended in $1 \mathrm{ml} 0.9 \% \mathrm{NaCl}$. The plate transformation assay was done as described (Lorenz \& Wackernagel, 1991). Mixtures of cells and DNA (10 $\mu$ l), either chromosomal (18 $\mu \mathrm{g}$ DNA ml ${ }^{-1}$ ) or PCR amplified (7-8 $\mu \mathrm{g}$ $646 \mathrm{bp}$ fragment of $r p o B \mathrm{ml}^{-1}$ ) were spotted on LB agar. DNA competition studies (see Fig. 2) were performed as follows: mixtures were prepared containing transformation-saturating concentrations of transforming Rif ${ }^{\mathrm{R}} \operatorname{LO} 179 \mathrm{DNA}\left(2 \mu \mathrm{g} \mathrm{ml}^{-1}\right)$, stationary phase LO179 cells $\left(5 \cdot 2 \pm 2 \cdot 0 \times 10^{9} \mathrm{ml}^{-1}\right)$ and competing non-transforming DNA at 2 to 10 -fold mass excess. Mixtures $(50 \mu \mathrm{l})$ were placed on LB plates and allowed to dry before incubating at $37^{\circ} \mathrm{C}$ for $2 \mathrm{~d}$. Thereafter the growth areas were cut out, cells were resuspended in $1 \mathrm{ml} 0.9 \% \mathrm{NaCl}$, $15 \mathrm{mM} \mathrm{MgCl}_{2}, 1 \mathrm{mM} \mathrm{CaCl}_{2}, 100 \mu \mathrm{g}$ DNase I ml ${ }^{-1}$ (incubation at $37^{\circ} \mathrm{C}$ for $10 \mathrm{~min}$ ) and the viable and $\mathrm{Rif}^{\mathrm{R}}$ counts were determined.

Amplification and sequencing of part of the RNA polymerase $\boldsymbol{\beta}$ gene. Amplification of part of the RNA polymerase $\beta$ gene of all strains except LO147, LO151, LO139 and LO145 was done in $50 \mu \mathrm{l}$ reaction mixtures including $25 \mathrm{ng}$ chromosomal DNA, $1 \mu \mathrm{M}$ primer + 43F (5'-CCGCAAGACCTGATCAACGCC3'; P. putida position 1514-1534, accession no. X15849) and primer +688R (5'-TGCCGGTACCCACCAGCG-3'; position 2142-2159), $50 \mu \mathrm{M}$ dNTPs (Pharmacia) and $1.0 \mathrm{U}$ Taq DNA Polymerase (Promega) in supplied reaction buffer. The following cycling protocol was performed: one cycle at $94{ }^{\circ} \mathrm{C}$ for $5 \mathrm{~min}, 40$ cycles of $94^{\circ} \mathrm{C}$ for $1 \mathrm{~min}, 64^{\circ} \mathrm{C}$ for $1 \mathrm{~min}$ and $72{ }^{\circ} \mathrm{C}$ for $3 \mathrm{~min}$, and a final primer extension at $72{ }^{\circ} \mathrm{C}$ for $10 \mathrm{~min}$ in a Perkin Elmer 480 apparatus. For strains LO147, LO151, LO139 and LO145, the amplification protocol was as 
Table 1. Sources and characteristics of strains used in this study

\begin{tabular}{|c|c|c|c|c|}
\hline Strain & Other designation(s)* & Source & Genomovar $\dagger$ & $\begin{array}{c}\text { Genotypic } \\
\text { group } \ddagger\end{array}$ \\
\hline \multicolumn{5}{|l|}{ P. stutzeri } \\
\hline $\mathrm{LO} 169^{\mathrm{T}}$ & DSM5190T $\mathbb{S}$, Stanier 221 & Clinical & 1 & $\mathrm{D}$ \\
\hline LO167 & ATCC $17589 \|$, Stanier 222 & Clinical & 1 & $\mathrm{D}$ \\
\hline LO171 & ATCC $17593 \|$, Stanier 226 & Clinical & ND & $\mathrm{D}$ \\
\hline LO147 & ATCC $17587 \|$, Stanier 220 & Clinical & 2 & $\mathrm{~A}$ \\
\hline LO151 & ATCC $17591 \|$, Stanier 224 & Clinical & 2 & A \\
\hline LO159 & ATCC $17685 \|$, Stanier 319 & Clinical & ND & $\mathrm{F} 29$ \\
\hline LO137 & DSM $50227 * *$ & Clinical & 3 & G \\
\hline LO199 & MW 56†† & Marine & ND & G \\
\hline LO139 & DSM $6084^{* *}$ & Marine & 4 & $\mathrm{E}$ \\
\hline LO145 & DSM 6082\$ & Wastewater & 5 & F1 \\
\hline LO179 & JM300\|, DSM 10701 & Soil & 8 & $\mathrm{H}$ \\
\hline LO177 & ATCC $17641 \|$, Stanier 275 & Clinical & ND & $\mathrm{H}$ \\
\hline $\begin{array}{l}\text { P. alcaligenes } \\
\text { LO } 165^{\mathrm{T}}\end{array}$ & $\operatorname{ATCC} 14909^{\mathrm{T}} \|$ & Wastewater & & $\mathrm{C}$ \\
\hline $\begin{array}{l}\text { P. mendocina } \\
\text { LO191 }\end{array}$ & $\operatorname{ATCC} 25411^{\mathrm{T}} \|$ & Soil & & I \\
\hline
\end{tabular}

*ATCC, American Type Culture Collection, Manassas, VA; DSM, Deutsche Sammlung von Mikroorganismen und Zellkulturen, Braunschweig, Germany.

†DNA hybridization group (Rosselló et al., 1991; Rosselló-Mora et al., 1996); ND, not determined.

‡According to analysis of combined genomic fingerprints (Sikorski et al., 1999).

SObtained from DSM.

\| Obtained from G. Stewart (West Georgia College, Georgia, USA).

g Clusters with genomovar 7 strain DSM 50238 according to 16S rRNA gene sequence analysis (Sikorski et al., 1999).

** Obtained from J. Lalucat (University of Mallorca, Spain).

†† Obtained from T. Höpner (University of Oldenburg, Germany).

above, except that primer annealing was at $58^{\circ} \mathrm{C}$ and internal primers $r p o B-\mathrm{F}_{\text {int }}$ (5'-CCAGCCAGCTNTCGCNGTTC-3'; position 1572-1591) and rpoB-R int (5'-CGGTTGGCGTCGTCGTGCTC-3'; position 2063-2082) were used. The PCR products were resolved on agarose gels $(1 \cdot 1 \%)$ including ethidium bromide. The bands of expected fragment size $(646$ bp ; 511 bp for LO147, LO139 and LO145) were extracted from the gel using the Qiagen Gel Extracting Kit. The purified PCR products were reamplified using the initial amplification protocol. The obtained PCR products were purified as above and then sequenced with primer $+43 \mathrm{~F}$ (primer $r p o B-\mathrm{F}_{\text {int }}$ for LO151, LO139 and LO145) employing the dye terminator technology. The nucleotide sequence data of partial $r p o B$ genes can be retrieved from the EMBL nucleotide sequence database under the following accession numbers: AJ279953 (LO177), AJ279954 (LO179), AJ279955 (LO151), AJ279956 (LO147), A J279958 (LO137), A J279959 (LO199), AJ279960 (LO159), AJ279961 (LO145), AJ279962 (LO169 ${ }^{\mathrm{T}}$ ), AJ279963 (LO171), A J279964 (LO167), AJ279965 (LO139), AJ279966 (LO165 $\left.{ }^{\mathrm{T}}\right)$, AJ279967 (LO191 $\left.{ }^{\mathrm{T}}\right)$.

Phylogenetic reconstruction and sequence divergence. Alignment of $r p o B$ sequences was done using CLUSTAL $\mathrm{x}$ version 1.64b (Thompson et al., 1997) with default parameters (gap opening $10 \cdot 00$, gap extension $0 \cdot 05$, delay divergent sequences $40 \%$, DNA transition weight $0 \cdot 50)$. The alignment was corrected manually. For phylogenetic analysis, a $422 \mathrm{nt}$ stretch from the alignment (Pseudomonas putida position 1591-2012) was used to generate a neighbour-joining dendrogram from a Jukes \& Cantor distance matrix (TREECON software; Van de Peer \& De Wachter, 1994). Bootstrap values were obtained with 100 replicates.

Statistical analysis. Experiments were repeated at least once. Statistical significance of differences between means was calculated using the Student's $t$-test.

\section{RESULTS}

\section{Transformability and competence}

For determination of natural transformability, each strain was grown on LB agar in the presence of DNA extracted from its own Rif $^{\mathrm{R}}$ mutant. During growth on plates, competence developed, DNA was taken up and recombined at homologous loci in the chromosome. Transformants were selected on rifampicin-containing medium. As a result, for $50 \%$ of the P. stutzeri strains, natural transformability was demonstrated (Table 2). The transformation frequencies reached varied over more than three orders of magnitude $\left[2.3 \times 10^{-7}\right.$ (LO139) to $1 \cdot 1 \times 10^{-3}$ (LO177)]. Five of the seven genotypic groups (A, D, E, F1, H; Table 2) contained at least one 
Table 2. Natural DNA uptake competence

\begin{tabular}{|c|c|c|c|c|c|c|c|}
\hline \multirow[t]{2}{*}{ Strain } & \multirow[t]{2}{*}{$\begin{array}{l}\text { Genotypic } \\
\text { group }\end{array}$} & \multicolumn{2}{|c|}{$\begin{array}{c}\mathrm{Rif}^{\mathrm{R}} \text { count } \mathrm{ml}^{-1} \\
\quad(\text { mean } \pm \mathrm{SD})\end{array}$} & \multirow{2}{*}{$\begin{array}{c}\text { Viable count } \\
\mathrm{ml}^{-1} \\
(\text { mean } \pm \mathrm{SD})\end{array}$} & \multicolumn{2}{|c|}{$\begin{array}{c}\text { Rif }^{\mathrm{R}} \text { frequency } \\
(\text { mean } \pm \mathrm{SD})\end{array}$} & \multirow[b]{2}{*}{$\begin{array}{r}\text { Transformation } \\
\text { demonstrated }\end{array}$} \\
\hline & & $\begin{array}{l}\text { With } \\
\text { DNA }\end{array}$ & $\begin{array}{l}\text { Without } \\
\text { DNA }\end{array}$ & & $\begin{array}{l}\text { With } \\
\text { DNA }\end{array}$ & $\begin{array}{l}\text { Without } \\
\text { DNA }\end{array}$ & \\
\hline \multicolumn{8}{|l|}{ P. stutzeri } \\
\hline LO169 $9^{\mathrm{T}}$ & D & $9 \cdot 8 \pm 5 \cdot 3 \times 10^{2}$ & $1 \cdot 8 \pm 1 \cdot 0 \times 10^{3}$ & $1.4 \pm 0.9 \times 10^{10}$ & $9 \cdot 0 \pm 6 \cdot 6 \times 10^{-8}$ & $1.4 \pm 0.9 \times 10^{-7}$ & - \\
\hline LO167 & $\mathrm{D}$ & $8 \cdot 2 \pm 6 \cdot 4 \times 10^{3}$ & $6 \cdot 6 \pm 5.4 \times 10^{2}$ & $4 \cdot 8 \pm 2 \cdot 1 \times 10^{9}$ & $1.1 \pm 0.4 \times 10^{-6 *}$ & $1.4 \pm 1.1 \times 10^{-7 *}$ & + \\
\hline LO171 & $\mathrm{D}$ & $6.4 \pm 2.7 \times 10^{2}$ & $6.5 \pm 3.4 \times 10^{2}$ & $1.5 \pm 0.9 \times 10^{10}$ & $5 \cdot 7 \pm 5 \cdot 2 \times 10^{-8}$ & $5.9 \pm 5.7 \times 10^{-8}$ & - \\
\hline LO147 & A & $1.8 \pm 0.6 \times 10^{6}$ & $4 \cdot 1 \pm 2 \cdot 1 \times 10^{2}$ & $6 \cdot 9 \pm 2.1 \times 10^{9}$ & $2.6 \pm 0.6 \times 10^{-4 *}$ & $7.5 \pm 5.5 \times 10^{-8: *}$ & + \\
\hline LO151 & A & $1 \cdot 2 \pm 0.6 \times 10^{3}$ & $1 \cdot 3 \pm 1 \cdot 3 \times 10^{3}$ & $1 \cdot 4 \pm 1 \cdot 0 \times 10^{10}$ & $8 \cdot 0 \pm 5 \cdot 3 \times 10^{-8}$ & $5 \cdot 1 \pm 4 \cdot 1 \times 10^{-8}$ & - \\
\hline LO159 & $\mathrm{F} 2$ & $1.4 \pm 0.6 \times 10^{3}$ & $8 \cdot 3 \pm 3 \cdot 5 \times 10^{2}$ & $1 \cdot 3 \pm 0 \cdot 6 \times 10^{10}$ & $1.6 \pm 1.0 \times 10^{-7}$ & $8 \cdot 8 \pm 5 \cdot 6 \times 10^{-8}$ & - \\
\hline LO137 & G & $2.5 \pm 1.5 \times 10^{2}$ & $4.4 \pm 3.0 \times 10^{2}$ & $6.5 \pm 2.5 \times 10^{9}$ & $6 \cdot 0 \pm 5.7 \times 10^{-8}$ & $5 \cdot 6 \pm 3.5 \times 10^{-8}$ & - \\
\hline LO199 & G & $4.9 \pm 3.0 \times 10^{2}$ & $8.3 \pm 6.9 \times 10^{2}$ & $5 \cdot 9 \pm 1.9 \times 10^{9}$ & $6.6 \pm 3.6 \times 10^{-8}$ & $1.2 \pm 1.0 \times 10^{-7}$ & - \\
\hline LO139 & $\mathrm{E}$ & $3.6 \pm 0.9 \times 10^{3}$ & $7 \cdot 7 \pm 5 \cdot 1 \times 10^{2}$ & $1 \cdot 3 \pm 0 \cdot 9 \times 10^{10}$ & $2 \cdot 3 \pm 0.9 \times 10^{-7 *}$ & $5 \cdot 0 \pm 3.9 \times 10^{-8 *}$ & + \\
\hline LO145 & $\mathrm{F}$ & $1 \cdot 7 \pm 0.9 \times 10^{3}$ & $3 \cdot 1 \pm 1 \cdot 7 \times 10^{2}$ & $1.2 \pm 0.5 \times 10^{9}$ & $1 \cdot 7 \pm 1.0 \times 10^{-6 *}$ & $2.8 \pm 0.7 \times 10^{-7 *}$ & + \\
\hline LO179 & $\mathrm{H}$ & $8 \cdot 4 \pm 3.3 \times 10^{5}$ & $1.6 \pm 0.6 \times 10^{2}$ & $1.3 \pm 0.5 \times 10^{10}$ & $7.5 \pm 4.7 \times 10^{-5 *}$ & $1.2 \pm 0.4 \times 10^{-8 * *}$ & + \\
\hline LO177 & $\mathrm{H}$ & $8 \cdot 3 \pm 6 \cdot 4 \times 10^{6}$ & $4.5 \pm 2.4 \times 10^{2}$ & $9 \cdot 1 \pm 2 \cdot 6 \times 10^{9}$ & $1.1 \pm 0.7 \times 10^{-3 *}$ & $5.7 \pm 4.0 \times 10^{-8 * *}$ & + \\
\hline \multicolumn{8}{|l|}{ P. alcaligenes } \\
\hline LO165 & $\mathrm{C}$ & $1.6 \pm 0.9 \times 10^{2}$ & $1 \cdot 7 \pm 1.6 \times 10^{2}$ & $6 \cdot 3 \pm 2 \cdot 1 \times 10^{9}$ & $3.2 \pm 0.7 \times 10^{-8}$ & $3 \cdot 0 \pm 1 \cdot 3 \times 10^{-8}$ & - \\
\hline \multicolumn{8}{|l|}{ P. mendocina } \\
\hline $\mathrm{LO}_{191^{\mathrm{T}}}$ & I & $7 \cdot 3 \pm 1 \cdot 4 \times 10^{3}$ & $2 \cdot 4 \pm 1.5 \times 10^{2}$ & $9 \cdot 0 \pm 5 \cdot 7 \times 10^{9}$ & $1.1 \pm 0.5 \times 10^{-6 *}$ & $2 \cdot 0 \pm 0 \cdot 3 \times 10^{-8 * *}$ & + \\
\hline
\end{tabular}

*Difference statistically significant $(P=0 \cdot 05, n=3-6)$.

transformable member. Pseudomonas mendocina LO191 ${ }^{\mathrm{T}}$ was transformable whereas transformation of Pseudomonas alcaligenes LO165 ${ }^{\mathrm{T}}$ could not be shown.

\section{Heterogamic transformation}

Transformable $P$. stutzeri strains with high competence were chosen as recipients in heterogamic transformation experiments for reasons of high sensitivity of detection. Therefore, LO147 (genotypic group A), LO177 and LO179 (both genotypic group H) were transformed with DNA isolated from Rif $^{\mathrm{R}}$ mutants of all strains used here. Sexual isolation between a recipient and particular donor strain was considered to exist in cases where the frequency of heterogamic transformation was significantly lower than the frequency of homogamic transformation (Cohan et al., 1991).

Using LO147 as a recipient, the transformation frequency with DNA from the other group A strain, LO151, was at a level $(P=0 \cdot 72, n=2)$ very similar to the frequency of homogamic transformation (Fig. 1a). This confirmed, on a genetic basis, the close relationship of LO147 with LO151. In contrast, heterogamic transformation of LO147 with donor DNA of P. mendocina LO $191^{\mathrm{T}}$ and $P$. alcaligenes LO165 ${ }^{\mathrm{T}}$ was nearly two orders of magnitude lower than in homogamic transformation (Fig. 1a). This indicated that $P$. stutzeri LO147 was sexually isolated from strains of the other species employed. Also, transformation frequencies with donors from $P$. stutzeri groups other than group A were significantly lower than in homogamic transformation $(P=0 \cdot 05, n=2)$, except LO169 ${ }^{\mathrm{T}}$ (group D; $\left.P=0 \cdot 14\right)$ and LO137 (group G; $P=0 \cdot 17, n=2$ ). The data indicated that LO147 is sexually isolated from at least eight of the ten $P$. stutzeri strains belonging to other groups. The levels of sexual isolation from other groups ranged from 0.5 to 1.2 orders of magnitude lower heterogamic than homogamic transformation frequencies and thus were lower than those from the other pseudomonad species.

Strain LO177 was transformed by its own DNA and DNA of the other member of group H, LO179, at comparable levels $(P=0.89, n=2$; Fig. 1b). With $P$. mendocina $\mathrm{LO} 191^{\mathrm{T}}$ and $P$. alcaligenes $\mathrm{LO} 165^{\mathrm{T}}$, a reduction of transformation frequencies by nearly three orders of magnitude was noticed compared to homogamic transformation. Heterogamic transformation with the $P$. stutzeri donors from other groups was also at decreased values, ranging from approximately 1 (e.g. group G) to 2.5 orders (group E, F1) of magnitude. Apparently, LO177 is sexually isolated from other pseudomonad species and also from other genotypic groups of $P$. stutzeri. As observed with LO147, LO177 was less sexually isolated from other P. stutzeri groups than from other species.

An unexpected finding was that the heterogamic transformation frequency of LO179 with DNA of the other group $\mathrm{H}$ strain, LO177, was more than two orders of magnitude lower than the transformation frequency with LO179 DNA. In fact, the level of transformation with the LO177 donor was at a level comparable with that of several strains from other groups (e.g. LO159, group F2; LO171, group D; Fig. 1c). Still other donors (e.g. LO151, group A; LO145, group F1) were as inefficient in transforming LO179 as were donors from the other pseudomonad species employed, the transformation frequencies lying in the range of the spontaneous mutation frequency (see Fig. 1). These results showed that LO179 is sexually isolated not only from other species and other $P$. stutzeri groups as observed with LO147 and LO177, but even from its next relative in the same group. 

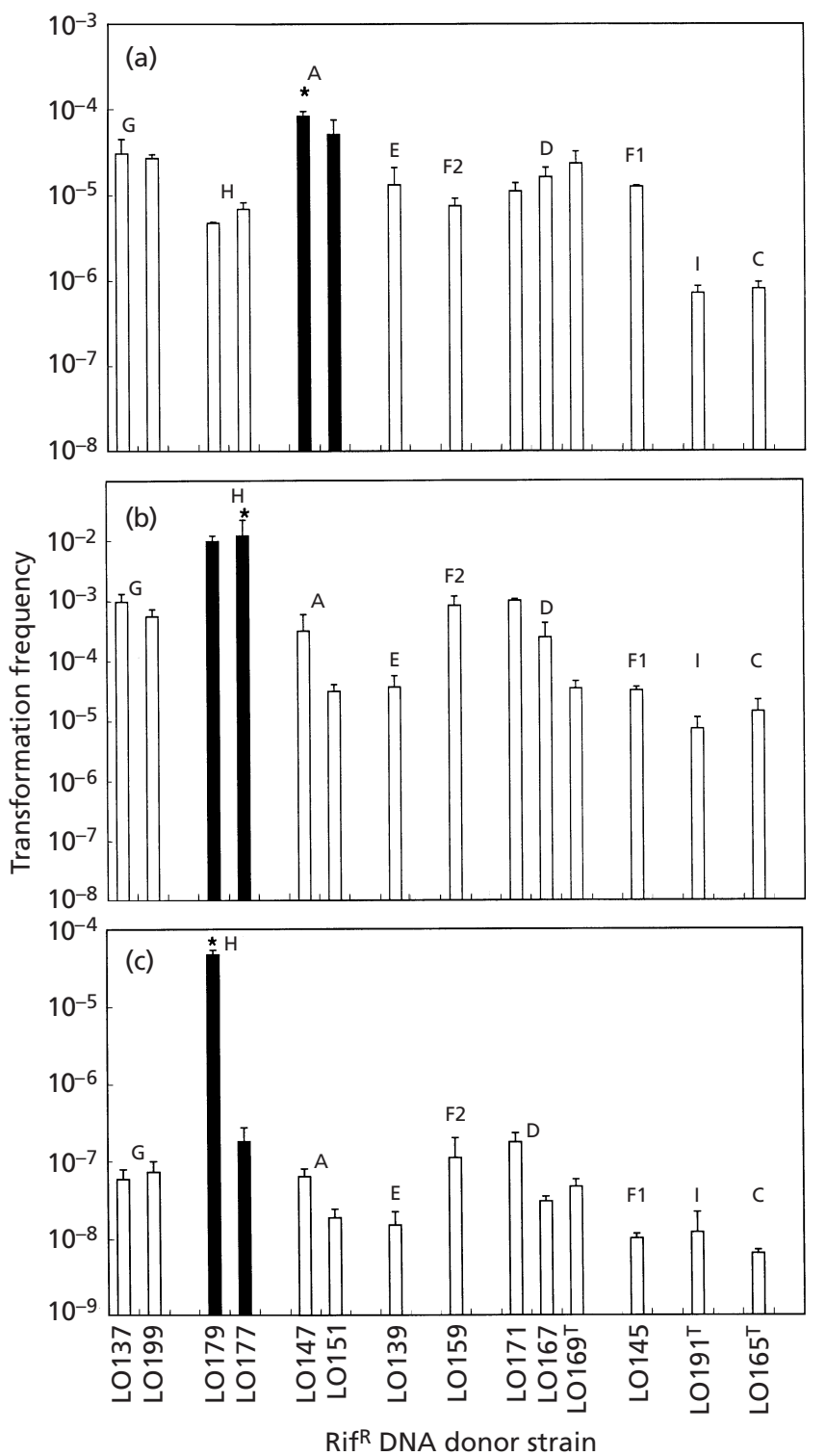

Fig. 1. Heterogamic transformation of LO147 (a), LO177 (b) and L0179 (c). Recipient strains (*) were transformed with DNA extracted from Rif ${ }^{R}$ mutants of strains belonging to the taxonomic groups as indicated by upper-case letters (see Table 1). Bars indicate deviation from the mean $(n=2)$. The limit of detection was $3.8 \pm 2.1 \times 10^{-8}\left(n=2 ;\right.$ LO147), $4.5 \pm 1.8 \times 10^{-8}(n$ $=3$; LO177) and $1.1 \pm 0.5 \times 10^{-8}\left(n=3\right.$; LO179) Rif ${ }^{R}$ frequency, respectively. Black bars indicate heterogamic transformations with donors from the same taxonomic group as the recipient.

\section{DNA competition}

The finding that LO179 was poorly transformed by DNA of the other group member, LO177 (Fig. 1c), prompted us to perform experiments on the specificity of DNA entry in LO179. Transformation of this strain is reported to be greatly insensitive to the presence of heterologous DNA [calf thymus, E. coli (Carlson et al., 1983; Lorenz et al., 1998; Lorenz \& Wackernagel, 1990)]. Therefore, DNA competition studies were done

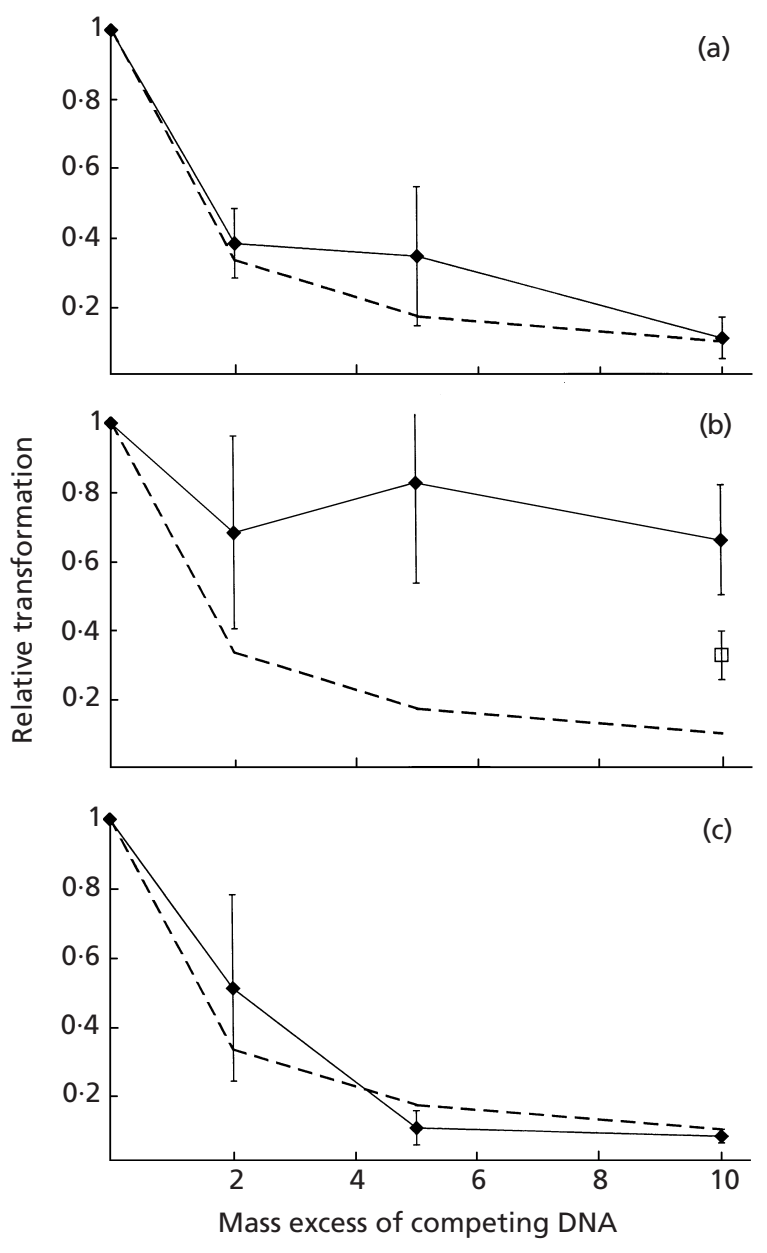

Fig. 2. Competition between homogamic and heterogamic DNA in transformation of LO179 (group H). Cells were grown on plates in the presence of saturating amounts of transforming homogamic DNA (Rif $\left.{ }^{\mathrm{R}}\right)$ and non-transforming (Rif $\left.{ }^{5}\right)$ DNA from isogenic strain JM306 (a), calf thymus (b), phage P22 (b, $\square$ ) and LO177 (c, group H) at the indicated mass excess. The dotted curve indicates the expected inhibition of transformation at proportional entry of transforming and competing non-transforming DNA into the cell. Values are means $(n=4 ; \square, n=2)$ and bars indicate deviation from the mean. Relative transformation is defined as the transformation frequency obtained with competing DNA divided by the transformation frequency obtained without competing DNA. A relative transformation of 1 corresponds to $4.4 \pm 2.7 \times 10^{-5}$ Rif $^{R}$ transformants $\mathrm{ml}^{-1}(n=4)$.

using homogamic transforming DNA $\left(\mathrm{Rif}^{\mathrm{R}}\right)$ and competing non-transforming (Rif $)$ DNA from various sources at increasing mass excess (Fig. 2).

In the control, inhibition of transformation matched the theoretical curve (Fig. 2a), that is, the transformation frequency declined proportionally to the amounts of competing non-transforming homogamic DNA added. Transformation was inhibited also by calf thymus DNA (Fig. 2b) albeit to a much lower extent than by competing homogamic DNA (Fig. 2a). For instance, at a 10-fold excess inhibition by calf thymus DNA was similarly low $(35 \%)$ as observed in previous experiments using 


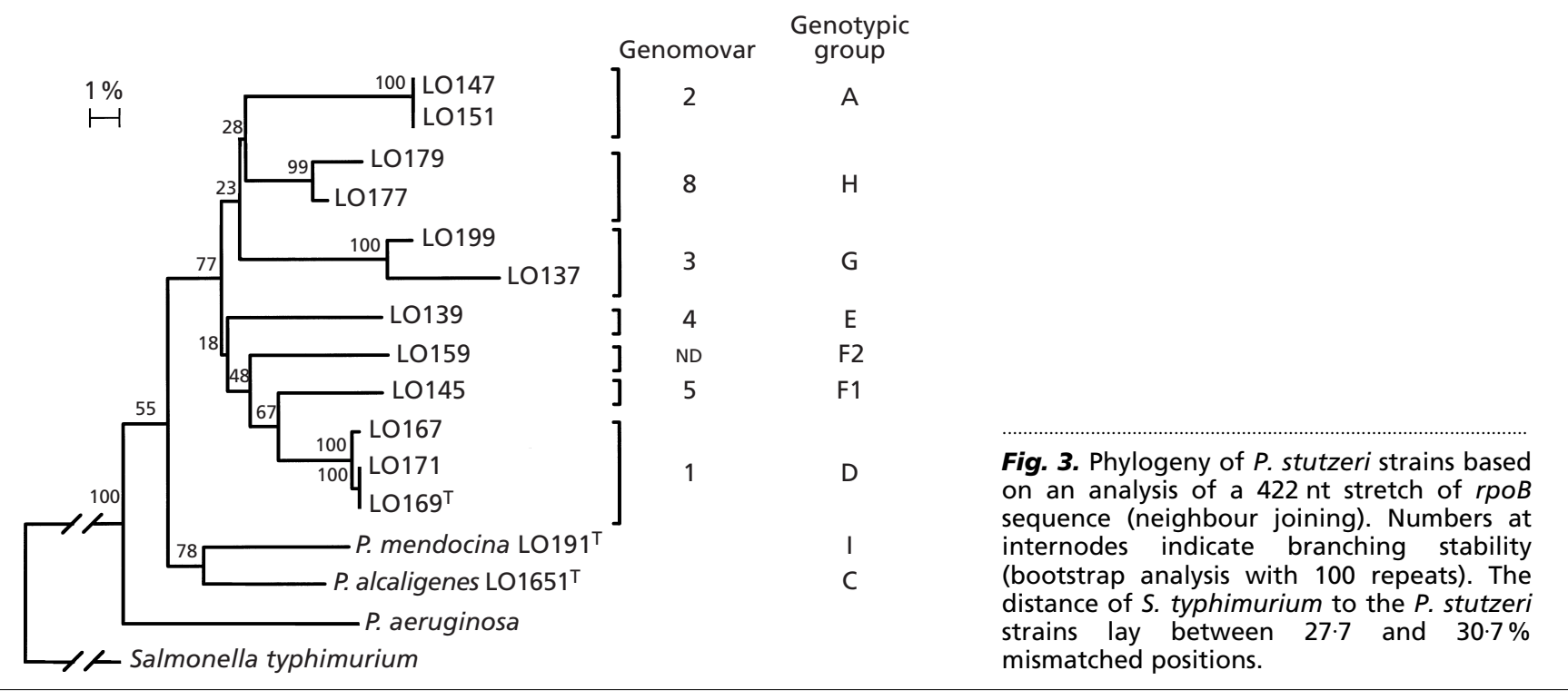

competing E. coli DNA (22\% ; Lorenz \& Wackernagel, 1990). Somewhat more inhibition of transformation was obtained with phage P22 DNA at 10-fold mass excess (Fig. 2b). However, the level of inhibition (68.5\%) was lower than expected $(91 \%)$. With increasing amounts of competing heterogamic Rif ${ }^{\mathrm{S}}$ LO177 DNA transformation of LO179 was reduced proportionally (Fig. 2c) similar to what was observed with competing nontransforming homogamic DNA (Fig. 2a). Hence we conclude that heterogamic LO177 DNA entered competent LO179 cells as freely as homogamic LO179 DNA.

\section{Phylogeny of $\boldsymbol{P}$. stutzeri based on $r p o B$ nucleotide sequence}

PCR primers were designed for amplification of a part of the gene encoding the $\beta$ subunit of RNA polymerase $(r p o B)$. For this purpose the $r p o B$ sequence of $P$. aeruginosa covering the region of rifampicin resistance (EMBL accession no. M99386) was aligned with the homologous sequence of $P$. putida (EMBL X15849). From this, primers $43 \mathrm{f}$ (P. putida position 1514) and 688r (position 2142) were constructed which gave amplification products of the expected size (646 bp) with all strains except strains LO147, LO151, LO139 and LO145. With these strains, an internal primer pair, $r p o B-\mathrm{F}_{\text {int }}$ and $r p o B-\mathrm{R}_{\text {int }}$ (P. putida positions 1572 and 2063 , respectively), of the 646 bp region resulted in an amplification product of the expected size (511 bp). Determination of the nucleotide sequence of the PCR products showed $82 \cdot 2-86.7 \%$ nucleotide sequence identity to the $r p o B$ region of $P$. aeruginosa (alignments with $422 \mathrm{bp}$ ).

A tree was constructed on the basis of $r p o B$ nucleotide sequences to analyse the genealogical relationships of the strains used. The results (Fig. 3) showed that, in accord with a previous tree obtained on the basis of $16 \mathrm{~S}$ rDNA sequences (Sikorski et al., 1999), all P. stutzeri strains grouped in a monophyletic branching pattern. Strains clustered in groups which were in harmony with the grouping pattern according to DNA hybridization (genomovars; Rosselló et al., 1991; Rosselló-Mora et al., 1996), 16S rDNA and genomic fingerprinting analyses (RREBM; Sikorski et al., 1999; see Table 1). However, the branching order of $r p o B$ clusters could not be resolved as indicated by the low values of the bootstrap analysis. This finding is equivalent to that of 16S rDNA analysis (Sikorski et al., 1999).

\section{The effect of nucleotide sequence divergence on sexual isolation}

The transforming activity of the PCR amplification products obtained with $\mathrm{Rif}^{\mathrm{R}}$ mutants of the $P$. stutzeri, $P$. mendocina and P. alcaligenes strains employed in this study were determined, using LO177, LO179 and LO147 as recipients, respectively. Transformants were obtained with the following donor strains: LO177, LO179, LO159, LO191 ${ }^{\mathrm{T}}$, LO165 ${ }^{\mathrm{T}}$, LO145 and LO139. This indicated that the amplified regions included mutations conferring rifampicin resistance in these strains. In the other strains, rifampicin resistance probably resulted from mutations outside the amplified region of $r p o B$.

Heterogamic transformation experiments were conducted that employed PCR-amplified $r p o B$ donor DNA with transforming activity, and LO179 and LO177 as recipients, respectively. Transformation of LO179 was very inefficient and the heterogamic transformation frequency with the LO177 PCR product already reached the detection limit. In contrast, LO177 was transformed at much higher frequencies by heterogamic PCR products (see below). Therefore, LO177 was used as a recipient in the following experiments. Transformation of LO177 showed a linear response $\left(1.8 \times 10^{-6}\right.$ $4.9 \times 10^{-5}$ transformation frequency) to the concentration of LO177 PCR amplified DNA (1.5-15 $\mu \mathrm{g}$ DNA ml $\mathrm{m}^{-1}$ ) and saturation was approximated at $18 \mu \mathrm{g}$ DNA ml $\mathrm{l}^{-1}\left(4 \cdot 1 \times 10^{-5}\right.$ transformation frequency). The correlation of sexual isolation, defined as the logtransformed data of the ratio of homogamic and 


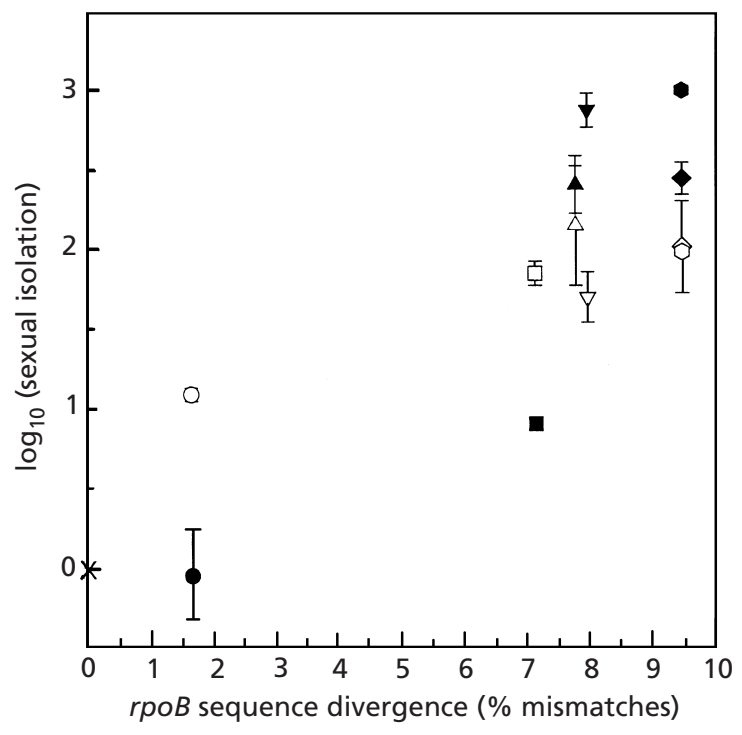

Fig. 4. Influence of sequence divergence on sexual isolation in transformations of LO177. The sequence divergence from L0177 was determined on the basis of mismatched sequence positions in alignments of 625 bases (LO179, LO159, LO165 ${ }^{\top}$ and LO191') or 422 bases (LO139 and LO145). White symbols indicate PCR-amplified $r p o B$ Rif ${ }^{R}$ fragment and black symbols Rif $^{R}$ chromosomal DNA. Bars show the deviation from the mean $(n=2)$. In some cases the deviation was too low to be indicated. Donors: $O$, LO179; $\square$, LO159; $\triangle$, LO139; $\nabla, \mathrm{LO}^{165^{\top}}$; $\diamond$, LO145; $\bigcirc$, LO191 $^{\top}$.

heterogamic transformation frequencies, and $r p o B$ sequence divergence ( $\%$ mismatches) was investigated. The results of this analysis (Fig. 4) indicated that sexual isolation increased with $r p o B$ sequence divergence. Sexual isolation increased over $1 \cdot 85 \log$ units up to $7 \cdot 2 \%$ mismatches (LO159). Values of sexual isolation hardly increased (1.7-2.15 log units; limit of detection, 2.46 log units) at higher degrees of sequence divergence of amplified donor rpoB DNA (7.8-9.5\% mismatches). The data of heterogamic transformations with chromosomal DNA from Fig. 1 were also included in the analysis. The results (Fig. 4) indicated that sexual isolation increased by $2.5 \log$ units up to $7.8 \%$ mismatches (LO139). At higher sequence divergence, sexual isolation increased only by another $0.5 \mathrm{log}$ units (limit of detection, 4.26 log units). A marked difference between sexual isolation values of PCR-amplified and chromosomal DNA transformations was noticed, in particular at $1.7 \%$ (LO179) and $7 \cdot 2 \%$ (LO159) mismatches.

\section{DISCUSSION}

\section{High variability in transformability and competence among strains}

P. stutzeri, a non-fluorescent member of the genus Pseudomonas, is a physiologically versatile organism indicated by its extreme variability in metabolic traits among isolated strains and also its capability of living on various recalcitrant compounds, including polyethylene glycols and environmental pollutants (Obradors \&
Aguilar, 1991; Rosselló-Mora et al., 1994; Stanier et al., 1966). It appears that selective pressure has guided this species to adapt to a variety of environments. Evidence gathers which leads to the view that extensive chromosomal rearrangements and recruitment of foreign genes are significant factors contributing to the evolution of P. stutzeri (Ginard et al., 1997; Rainey et al., 1994; Sikorski et al., 1999; Vermeiren et al., 1999).

The potential of $P$. stutzeri for intraspecific horizontal gene transfer by transformation was investigated. For six strains falling into five of the seven genomic groups, transformability to rifampicin resistance was demonstrated (Table 2). For the other six strains, the Rif $^{\mathrm{R}}$ frequencies in experiments with and without DNA could not be distinguished. These strains may have developed only extremely low, if any, DNA uptake competence under the conditions employed here. The data are in overall accord with previous qualitative transformability assays (Carlson et al., 1983), except that for one strain (LO151) reported transformability could not be supported here. A qualitative effect of the DNA preparation or a marker effect is probably not an explanation for the observed lack of transformability because LO151 DNA transformed LO147 at high frequency (Fig. 1). The fact that transformability of $P$. stutzeri is confined to distinct strains and not a general phenomenon of the species matches observations made with other transformable species including a B. subtilis natural population (85\% transformable strains; Cohan et al., 1991) and H. influenzae clinical isolates (42\% transformable strains; Rowji et al., 1989). Among the transformable P. stutzeri strains, variation of the level of competence was high (three orders of magnitude, Table 2 ) and thus comparable to ranges in competence found with B. subtilis and $H$. influenzae (Cohan et al., 1991; Rowji et al., 1989). It appears that some strains have a higher potential for gene acquisition than others developing low or no competence. However, whether this is true in the natural environment is not clear inasmuch as competence in P. stutzeri (LO179) can increase as a response to nutrient starvation (Lorenz \& Wackernagel, 1991). It can not be excluded that strains, including those with low competence under standardized high-nutrient conditions, may have an increased capability of DNA uptake in the environment.

The evolutionary impact leading to the observed polymorphism in transformability and competence levels in $P$. stutzeri is not known. In another transformable species, S. pneumoniae, lack of transformability was associated with a deficiency in the production of competence factor (Yother et al., 1986). Perhaps allelic variation of competence genes also accounts for the different phenotypes observed among $P$. stutzeri strains. Variation in competence levels could be a reflection of niche-specific selection as Rainey et al. (1994) proposed with regard to the considerable heterogeneity in other phenotypic properties including fatty acid and substrate utilization profiles among strains. On the other hand, Cohan et al. (1991) interpreted their results of high variability of competence levels within a natural popu- 
lation of B. subtilis as an indication of low, if any, selection on rates of recombination. Clearly, more information is necessary with regard to competence levels in natural populations of $P$. stutzeri from different geographical locations and habitats in order to address this problem.

\section{Sexual isolation among and within $P$. stutzeri taxonomic groups}

Isolates from different habitats were found in common genotypic groups ( $\mathrm{H}$ and $\mathrm{G}$; Tables 1 and 2). Preliminary results obtained with wild isolates from a marine sediment suggested that $P$. stutzeri strains from different 16S rRNA gene sequence clusters can inhabit common ecological niches (J. Sikorski, N. Teschner \& W. Wackernagel, unpublished results). It has been reported previously that DNA can be taken up in marine sediment and soil microcosms by added competent bacteria including $P$. stutzeri and that transformation among genetically marked isogenic strains can occur in nonsterile soil (Gallori et al., 1994; Lorenz et al., 1988; Nielsen et al., 1997; Paul et al., 1991; Romanowski et al., 1993; Sikorski et al., 1998; Stewart et al., 1991).

A major finding of this study was that heterogamic transformation frequencies of three recipients from two groups with DNA of representatives of other groups and species were significantly lower than homogamic transformation frequencies (Fig. 1). This indicated that mechanisms exist in these two taxonomic groups that lead to sexual isolation from other groups and species. This may hold true also for transformable members of the other groups of $P$. stutzeri. Apparently, sexual isolation is a quantitative character in $P$. stutzeri transformation. This adds to findings obtained with a $B$. subtilis desert soil population (Cohan et al., 1991). The levels of sexual isolation determined in P. stutzeri were considerably different among the three recipients tested (Fig. 1). Group A strain LO147 (Fig. 1a) was least isolated from the other $P$. stutzeri groups (maximally by a factor of 17 from group $\mathrm{H}$ ), followed by group $\mathrm{H}$ strains with considerably higher sexual isolation (LO177) up to a factor of 300 from group $\mathrm{E}$ and LO179 up to a factor of 4000 from group F1. A striking observation was that within group $\mathrm{H}$, LO179 was sexually isolated from LO177 (Fig. 1c). This was not reciprocal: LO177 was transformed at similar frequencies by its own and by LO179 DNA (Fig. 1b). Collectively these data add to the great genotypic diversity found in P. stutzeri. Some strains like LO147 (group A) may be transformed by heterogamic DNA from other $P$. stutzeri groups more readily than others like LO177 and LO179 (group H).

\section{Free entry of heterogamic DNA into competent cells}

DNA competition studies indicated that transformation of LO179 was only partially inhibited by an excess of heterologous calf thymus DNA (Fig. 2b). This suggested discrimination of unrelated DNA during uptake. However, it is improbable that a mechanism exists in LO179 that is like other transformation systems including those operative in N. gonorrhoeae and H. influenzae where discrimination against heterologous DNA during transport into the cell is strict when the donor DNA lacks specific recognition sequences required for uptake (for a review see Lorenz \& Wackernagel, 1994). The finding that unrelated phage P22 DNA showed considerable inhibition of LO179 transformation (although not as high as expected when DNA of any source enters the cell at equal probability; see Fig. 2b) supports this conclusion. The observation of non-proportional inhibition of LO179 transformation by unrelated DNA requires further experimentation which, however, is out of the scope of the present study. With regard to the objective of this study it is relevant to note that similar inhibition patterns of transformation were observed when competing non-transforming homogamic and heterogamic LO177 DNA were employed in competition studies (compare Fig. 2a and c). This allows us to conclude that LO177 DNA was taken up as efficiently as homogamic DNA by competent LO179 cells. Similar results were obtained with LO177 as recipient and competing Rif ${ }^{\mathrm{S}}$ homogamic and LO179 DNA (data not shown). Hence inefficient uptake of heterogamic DNA is not an explanation for sexual isolation of LO179 from LO177. This probably also holds true for transformations of LO179 employing DNAs from other groups and the other Pseudomonas species: DNA from a P. stutzeri strain that, according to genomic fingerprint and phylogenetic analysis (16S rDNA), was shown to be most closely related to P. mendocina (J. Sikorski \& M. G. Lorenz, unpublished results) inhibited transformation of LO179 in a similar pattern as did homogamic nontransforming DNA (data not shown).

\section{Sensitivity of sexual isolation to nucleotide sequence divergence}

The level of sexual isolation of LO177 increased with $r p o B$ sequence divergence both with PCR-amplified and chromosomal DNA (Fig. 4). However, the quantitative effects on sexual isolation were very different. With PCR-amplified Rif ${ }^{\mathrm{R}}$ DNA, the next closest relative, LO179, was clearly isolated from LO177, whereas an effect of sequence divergence was not apparent with chromosomal LO179 DNA. Further, there was a markedly (0.95 log units) higher extent of sexual isolation with PCR-amplified DNA than with chromosomal DNA at $7 \cdot 2 \%$ mismatched sequences (LO159). In their studies employing a B. subtilis population, Roberts \& Cohan (1993) discussed the lower sensitivity of sexual isolation on sequence divergence in transformation with large chromosomal DNA fragments compared to small DNA molecules (PCR-amplified 3366 bp rpoB fragment) as an effect of the increased stability of long-stretched flanking sequences in the heteroduplex. This hypothesis would also explain the observations made with LO177. With $B$. subtilis 168 Marburg donor strain and natural isolates as recipients, Zawadzki et al. (1995) found a log-linear relationship between sexual isolation and sequence divergence. The data of this study do not show such a 
relationship regardless of whether PCR-amplified or chromosomal DNA was used (Fig. 4). Sexual isolation increased up to $7 \cdot 2 \%$ mismatches and hardly responded to sequence divergence at more than $7 \cdot 8 \%$ mismatches (LO139). This finding is reminiscent of other results obtained with B. subtilis YB886, a derivative of the Marburg strain (Zawadzki et al., 1995), which showed a pattern of sensitivity of sexual isolation to sequence divergence that is considerably different to other $B$. subtilis recipients. The authors concluded that evolution in this organism can proceed in the direction of nonloglinear patterns of sexual isolation. The genetic basis leading to modulation in the sensitivity of sexual isolation towards sequence divergence is obscure, but allelic variation of recombination pathways could play a role (Zawadzki et al., 1995). Also, differences in proofreading enzyme activities may cause large differences in the sensitivity of sexual isolation to sequence divergence (discussed by Roberts \& Cohan, 1993). Whether this holds true for heterogamic transformation in $P$. stutzeri has yet to be shown. The enormous genomic and allelic diversity in housekeeping functions found in P. stutzeri (Sikorski et al., 1999) leads us to expect differences in the response of sexual isolation to sequence divergence. It may be of interest to study this topic in more detail with other recipients including new wild isolates.

\section{Conclusions}

Sexual isolation with regard to transformation has been demonstrated here to exist in P. stutzeri. The potential to receive genes can vary greatly among strains as an effect of heterogeneity in transformability, quantitative differences in competence development, sequence divergence that could affect heteroduplex formation between donor and recipient systems and other genetic factors not identified so far (leading to sexual isolation even between closely related strains as observed with LO179). Further, differences in ecological constraints among microhabitats can influence recombination probabilities such as modulation of competence by nutrient availability and quality, temperature, and secretion of DNases (Lorenz \& Wackernagel, 1991, 1992; Sikorski et al., 1998). The results obtained here add to the view on the basis of work on B. subtilis (Zawadzki et al., 1995) that distinct lineages (e.g. genomovars, pathovars) within transformable species, for many of which population structures have been found that infer panmixis (for a review see Lorenz, 1998), are free to diverge in neutral sequence characters as a result of sexual isolation mechanisms which prevent allelic randomization. Nevertheless, this border is not absolute, and foreign sequences may be acquired and fixed in a way similar to what has driven the recruitment of nitrogen fixation genes in particular $P$. stutzeri strains (Vermeiren et al., 1999).

\section{ACKNOWLEDGEMENTS}

This work was supported by grant 0311217 of the Bundesminister für Bildung, Wissenschaft, Forschung und Technologie, which is gratefully acknowledged.

\section{REFERENCES}

Albritton, W. L., Setlow, J. K., Thomas, M., Sottnek, F. \& Steigerwalt, A. G. (1984). Heterospecific transformation in the genus Haemophilus. Mol Gen Genet 193, 358-363.

Bennasar, A., Guasp, C., Tesar, M. \& Lalucat, J. (1998). Genetic relationships among Pseudomonas stutzeri strains based on molecular typing methods. J Appl Microbiol 85, 643-656.

Bertolla, F., Frostegard, A., Brito, B., Nesme, X. \& Simonet, P. (1999). During infection of its host, the plant pathogen Ralstonia solanacearum naturally develops a state of competence and exchanges genetic material. Mol Plant-Microbe Interact 12, 467-472.

Carlson, C. A., Pierson, L. S., Rosen, J. J. \& Ingraham, J. L. (1983). Pseudomonas stutzeri and related species undergo natural transformation. J Bacteriol 153, 93-99.

Cohan, F. M., Roberts, M. S. \& King, E. C. (1991). The potential for genetic exchange by transformation within a natural population of Bacillus subtilis. Evolution 45, 1383-1421.

Davis, R. W., Botstein, D. \& Roth, J. R. (1980). Advanced Bacterial Genetics. Cold Spring Harbor, NY: Cold Spring Harbor Laboratory.

Dubnau, D. (1999). DNA uptake in bacteria. Annu Rev Microbiol 53, 217-244.

Duncan, K. E., Ferguson, N., Kimura, K., Zhou, X. \& Istock, C. (1994). Fine-scale genetic and phenotypic structure in natural populations of Bacillus subtilis and Bacillus licheniformis: implications for bacterial evolution and speciation. Evolution 48, 2002-2025.

Gallori, E., Bazzicalupo, M., Dal Canto, L., Fani, R., Nannipieri, P., Vettori, C. \& Stotzky, G. (1994). Transformation of Bacillus subtilis by DNA bound on clay in non-sterile soil. FEMS Microbiol Ecol 15, 119-126.

Ginard, M., Lalucat, J., Tuemmler, B. \& Roemling, U. (1997). Genome organization of Pseudomonas stutzeri and resulting taxonomic and evolutionary considerations. Int J Syst Bacteriol 47, 132-143.

Go, M. F., Kapur, V., Graham, D. Y. \& Musser, J. M. (1996). Population genetic analysis of Helicobacter pylori by multilocus enzyme electrophoresis: extensive allelic diversity and recombinational population structure. J Bacteriol 178, 3934-3938.

Grossman, A. D. (1995). Genetic networks controlling the initiation of sporulation and the development of genetic competence in Bacillus subtilis. Annu Rev Genet 29, 477-508.

Haubold, B., Travisano, M., Rainey, P. B. \& Hudson, R. R. (1998). Detecting linkage disequilibrium in bacterial populations. Genetics 150, 1341-1348.

Hermanns, U. \& Wackernagel, W. (1977). The recBC enzyme of Escherichia coli K12: premature cessation of catalytic activities in vitro and reactivation by potassium ions. Eur J Biochem 76, 425-432.

Istock, C. A., Duncan, K. E., Ferguson, N. \& Zhou, X. (1992). Sexuality in a natural population of bacteria - Bacillus subtilis challenges the clonal paradigm. Mol Ecol 1, 95-103.

Lorenz, M. G. (1998). Horizontal gene transfer among bacteria in soil by natural genetic transformation. In Microbial Interactions in Agriculture and Forestry, pp. 19-44. Edited by N. S. Subba Rao \& Y. R. Dommergues. Enfield, NH: Science Publishers.

Lorenz, M. G. \& Wackernagel, W. (1990). Natural genetic transformation of Pseudomonas stutzeri by sand-adsorbed DNA. Arch Microbiol 154, 380-385.

Lorenz, M. G. \& Wackernagel, W. (1991). High frequency of 
natural genetic transformation of Pseudomonas stutzeri in soil extract supplemented with a carbon/energy and phosphorus source. Appl Environ Microbiol 57, 1246-1251.

Lorenz, M. G. \& Wackernagel, W. (1992). Stimulation of natural genetic transformation of Pseudomonas stutzeri in extracts of various soils by nitrogen or phosphorus limitation and influence of temperature and pH. Microb Releases 1, 173-176.

Lorenz, M. G. \& Wackernagel, W. (1994). Bacterial gene transfer by natural genetic transformation in the environment. Microbiol Rev 58, 563-602.

Lorenz, M. G., Aardema, B. W. \& Wackernagel, W. (1988). Highly efficient genetic transformation of Bacillus subtilis attached to sand grains. J Gen Microbiol 134, 107-112.

Lorenz, M. G., Meyer, B., Wittstock, M., Graupner, S. \& Wackernagel, W. (1998). Selective DNA uptake and DNA restriction as barriers to horizontal gene exchange by natural genetic transformation in Pseudomonas stutzeri JM300. In Horizontal Gene Transfer, pp. 131-143. Edited by M. Syvanen \& C. I. Kado. London: Chapman \& Hall.

Majewski, J. \& Cohan, F. M. (1999). DNA sequence similarity requirements for interspecific recombination in Bacillus. Genetics 153, 1525-1533.

Marmur, J. (1961). A procedure for isolation of deoxyribonucleic acid from microorganisms. J Mol Biol 3, 208-218.

Maynard Smith, J., Dowson, C. G. \& Spratt, B. G. (1991). Localized sex in bacteria. Nature 349, 29-31.

Maynard Smith, J., Smith, N. H., O'Rourke, M. \& Spratt, B. G. (1993). How clonal are bacteria? Proc Natl Acad Sci US A 90, 4384-4388.

Müller-Graf, C. D. M., Whatmore, A. M., King, S. J. \& 7 other authors (1999). Population biology of Streptococcus pneumoniae isolated from oropharyngeal carriage and invasive disease. Microbiology 145, 3283-3293.

Nielsen, K. M., van Weerelt, M. D. M., Berg, T. N., Bones, A. M., Hagler, A. N. \& van Elsas, J. D. (1997). Natural transformation and availability of transforming DNA to Acinetobacter calcoaceticus in soil microcosms. Appl Environ Microbiol 63, 1945-1952.

Obradors, N. \& Aguilar, J. (1991). Efficient biodegradation of high-molecular-weight polyethylene glycols by pure cultures of Pseudomonas stutzeri. Appl Environ Microbiol 57, 2383-2388.

Paget, E. \& Simonet, P. (1994). On the track of natural transformation in soil. FEMS Microbiol Ecol 15, 109-118.

Paul, J. H., Frischer, M. E. \& Thurmond, J. M. (1991). Gene transfer in marine water column and sediment microcosms by natural plasmid transformation. Appl Environ Microbiol 57, 1509-1515.

Rainey, P. B., Thompson, I. P. \& Palleroni, N. J. (1994). Genome and fatty acid analysis of Pseudomonas stutzeri. Int J Syst Bacteriol 44, 54-61.

Roberts, M. S. \& Cohan, F. M. (1993). The effect of DNA sequence divergence on sexual isolation in Bacillus. Genetics 134, 401-408.

Roberts, M. S. \& Cohan, F. M. (1995). Recombination and migration rates in natural populations of Bacillus subtilis and Bacillus mojavensis. Evolution 49, 1081-1094.

Robertson, B. D. \& Meyer, T. F. (1992). Genetic variation in pathogenic bacteria. Trends Genet 8, 422-427.
Romanowski, G., Lorenz, M. G. \& Wackernagel, W. (1993). Plasmid DNA in a groundwater aquifer microcosm - adsorption, DNase resistance and natural genetic transformation of Bacillus subtilis. Mol Ecol 2, 171-181.

Rosselló, R., Garcia-Valdes, E., Lalucat, J. \& Ursing, J. (1991). Genotypic and phenotypic diversity of Pseudomonas stutzeri. Syst Appl Microbiol 14, 150-157.

Rosselló-Mora, R. A., Lalucat, J., Dott, W. \& Kämpfer, P. (1994). Biochemical and chemotaxonomic characterization of Pseudomonas stutzeri genomovars. J Appl Bacteriol 76, 226-233.

Rosselló-Mora, R. A., Lalucat, J. \& Moore, E. R. B. (1996). Strain JM300 represents a new genomovar within Pseudomonas stutzeri. Syst Appl Microbiol 19, 596-599.

Rowji, P., Gromkova, R. \& Koornhof, H. (1989). Genetic transformation in encapsulated clinical isolates of Haemophilus influenzae type b. J Gen Microbiol 135, 2775-2782.

Sikorski, J., Graupner, S., Lorenz, M. G. \& Wackernagel, W. (1998). Natural genetic transformation of Pseudomonas stutzeri in a non-sterile soil. Microbiology 144, 569-576.

Sikorski, J., Rosselló-Mora, R. \& Lorenz, M. G. (1999). Analysis of genotypic diversity and relationships among Pseudomonas stutzeri strains by PCR-based genomic fingerprinting and multilocus enzyme electrophoresis. Syst Appl Microbiol 22, 393-402.

Stanier, R. Y., Palleroni, N. J. \& Doudoroff, M. (1966). The aerobic pseudomonads: a taxonomic study. J Gen Microbiol 43, 159-271.

Stewart, G. J., Sinigalliano, C. D. \& Garko, K. A. (1991). Binding of exogenous DNA to marine sediments and the effect of DNA/ sediment binding on natural transformation of Pseudomonas stutzeri strain ZoBell in sediment columns. FEMS Microbiol Ecol 85, 1-8.

Thompson, J. D., Gibson, T. J., Plewniak, F., Jeanmougin, F. \& Higgins, D. G. (1997). The CLUSTAL x windows interface: flexible strategies for multiple sequence alignment aided by quality analysis tools. Nucleic Acids Res 24, 4876-4882.

Van de Peer, Y. \& De Wachter, R. (1994). TREeCON for Windows: a software package for the construction and drawing of evolutionary trees for the Microsoft Windows environment. Comput Appl Biosci 10, 569-570.

Vermeiren, H., Willems, A., Schoofs, G., de Mot, R., Keijers, V., Hai, W. \& Vanderleyden, J. (1999). The rice inoculant strain Alcaligenes faecalis A15 is a nitrogen-fixing Pseudomonas stutzeri. Syst Appl Microbiol 22, 215-224.

Wise, M. G., Shimkets, L. J. \& McArthur, J. V. (1995). Genetic structure of a lotic population of Burkholderia (Pseudomonas) cepacia. Appl Environ Microbiol 61, 1791-1798.

Yother, J., McDaniel, L. S. \& Briles, D. E. (1986). Transformation of encapsulated Streptococcus pneumoniae. J Bacteriol 168, 1463-1465.

Zawadzki, P., Roberts, M. S. \& Cohan, F. M. (1995). The log-linear relationship between sexual isolation and sequence divergence in Bacillus transformation is robust. Genetics 140, 917-932.

Received 25 April 2000; revised 14 August 2000; accepted 4 September 2000. 